\title{
The URBAN programme and the European urban policy discourse: successful instruments to Europeanize the urban level?
}

\author{
Thea Dukes
}

Published online: 3 July 2008

(C) The Author(s) 2008

\begin{abstract}
The European Community Initiative URBAN, explored in this article for seven countries in general and for two individual cities in the Netherlands in more detail, is a micro example of the ongoing struggle between European and national policy actors who contest each others' authority. The programme, aimed at solving social-economic problems in deprived neighbourhoods in European cities, has acted as a catalyst for new forms of cooperation. Whether it has directly contributed to Europeanization at the local level seems questionable, but it has certainly helped some city administrations to enter the European stage. Whereas European urban policy discourse could not be found at the Dutch urban level in the mid 1990s, the discourse has become dispersed and is now increasingly used.
\end{abstract}

Keywords Community Initiative URBAN . Governance - European urban policy discourse . Europeanization $\cdot$ The Netherlands

\section{Introduction}

In 1994, the European Commission launched the Community Initiative URBAN. The programme pursued ways to tackle the high concentration of social, environmental and economic problems that were

T. Dukes $(\bowtie)$

AMIDSt, University of Amsterdam, Nieuwe

Prinsengracht 130, 1018 VZ Amsterdam, The Netherlands

e-mail: M.J.M.Dukes@uva.nl stated to be increasingly present in European cities. It consisted of a first round (1994-1999, 'URBAN-I') and a second round (2000-2006, 'URBAN II').

Like the European Urban Pilot Programme (19901999), URBAN focused on urban areas. It targeted relatively small areas $\left(5.8 \mathrm{~km}^{2}\right.$ on average as it turned out after implementation) in extremely deprived urban neighbourhoods. Moreover, traditional physical measures of urban renewal were combined with social and economic initiatives. These new approaches (spatial, integrated) distinguished the programme from thematically organized policies and preceding urban programmes.

The European Commission proposed the Community Initiative URBAN to the Member States on its own initiative. In this sense, the programme provided an opportunity for the EU to enhance its visibility in the Member States. The programme took place under the heading of European Regional policy and was financed by the Structural Funds, that were, in turn, framed by the EU Treaties. Important principles enshrined in the Treaties (subsidiarity, for example) and in the Structural Fund Regulations (partnership, for example) therefore also applied to URBAN. Whereas the programme was quite modest from a financial perspective, ${ }^{1}$ its organisational requirements

\footnotetext{
1 While the total budget for the Structural Funds for 19941999 was about 154,5 billion euro at 1994 prices, for example, the CI URBAN budget for that period amounted to 900 million euros (EC 1997).
} 
broke ground for new forms of cooperation in urban policy. Moreover, it opened up opportunities for cities to interact directly with 'Brussels'.

Member state authorities could submit operational programmes for funding within the URBAN framework, but as the main financier, the European Commission was in the position to make specific organizational requirements: actors had to be organized in local partnerships, both in terms of cooperation between partners from different governmental levels, and in terms of cooperation between public and private actors. Community or volunteer groups had to be represented in the operational URBAN organization structures as well. Strikingly, the European Commission also claimed a role for itself in the organisation of these operational programmes. Whereas one would expect that the principle of subsidiarity discouraged this possibility, the partnership principle actually encouraged to do so. ${ }^{2}$

One could argue that URBAN, with its 'microzoning' approach and its organisational requirements of local partnership and participation, constructed a particular territorial sub-division within the territorial control of administrative structures of governance in the Member States. This could put these structures under pressure and possibly even contribute to the process of Europeanization. Besides, the involvement of subnational actors in European urban programmes could be experienced by the national governments of the member states as European interference in their domestic administrative structures. For that reason, one could imagine contestation of positions in this urban arena, amongst others between the European Commission and member state authorities, navigating between legally anchored concepts like subsidiarity and partnership.

In connexion with the development of European urban policy, in the past decades a particular jargon has come into being. If one examines official EU sources on urban policy, they contain a specific policy vocabulary that is made up of a limited number of terms. These terms are constructed and used in story-lines in various, but constantly recurring ways. Because of this

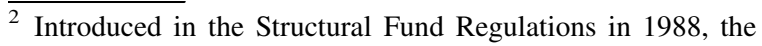
partnership principle sought to develop lasting partnerships among the European Commission, the national governments and sub-national authorities, in order to improve vertical coordination (Anderson 1995). In that sense, the partnership principle fulfilled a crucial role in the process of European integration and Europeanization.
}

recurring, systematic way of constructing social reality, one can speak of a 'European urban policy discourse'. This discourse is a construction of social reality, in which particular meanings are assigned to 'cities' and to actors involved in European urban policy. It is connected to European debates on regional policy, partnership, governance, etc. all of which are part of a wider discourse that Christiansen, Jorgensen and Wiener (1999, p. 541) describe as 'Euro-speak' and characterize as

"the purpose-built vocabulary of terms to describe (and shape) the reality of the EU."

Treaties, directives and communications of European institutions all speak this specific and unique language. While 'Euro-speak' was initially only understood by a limited circle of insiders, in the opinion of the authors, due to the growing importance of EU policies in the 1990s, nowadays a far wider group shares this language.

Examining European urban policy discourse is interesting for at least two reasons. First, because of the increasing interaction between the European, national, regional and local levels in European regional policy and in specific programmes such as URBAN, one could imagine that this discourse has become widely spread and possibly influential, in the member states. If this is the case, one could even qualify it as an element of Europeanization. Second, one could imagine that the earlier mentioned issue of contestation of authority, as played out in and over the URBAN territories, would be expressed in this particular discourse.

Based on the foregoing, in this article, two research questions will be addressed:

1. What has been the impact of URBAN on domestic governance structures? How have actors at different tiers of government reacted to pressures emanating from URBAN to adjust existing domestic urban policy contents, patterns and instruments to EU requirements?

2. Focusing on the Netherlands and using a discourse analysis, what has been the role of European urban policy discourse in this sense? Has it been used for the negotiation of (especially) governance issues? To what extent has it been influential at the different tiers of government?

Fieldwork on which this article draws has been conducted for a dissertation, focusing primarily on 
URBAN programmes in the Netherlands (Dukes 2006a). Two Dutch URBAN-I programmes that were implemented in the mid $1990 \mathrm{~s}$, URBAN Bijlmermeer in Amsterdam and URBAN Schilderswijk in The Hague, have served as elaborate examples. The author also contributed to a comparative URBACT report, published in 2006 by the Berlin Humboldt University (Frank et al. 2006). As a general conclusion from these questions, we will indicate to what extent URBAN and European urban policy discourse could be qualified as successful in terms of their contribution to Europeanization at the urban level.

\section{The impact of URBAN on governance structures and dynamics}

What has been the actual impact of URBAN on (national and sub-national) governance structures and dynamics? And what have been the responses of actors at these tiers of government to these pressures?

As 'governance' plays an essential role in these questions, before turning to the actual impact of URBAN on governance structures and dynamics, it is important first to briefly elaborate on the concept of governance.

Exploring the concept of governance

While the debate on governance is highly compartmentalized, Pierre (2000) argues that the overarching questions in the debate relate to new forms and shapes that the pursuit of the collective interest can and should take; the extent in which the traditional, liberaldemocratic model of the state should be rethought and also the steering instruments with which the state has to impose its will on society and on the economy.

Kooiman (2003) distinguishes different forms of governance: self governance, meaning the governance capacity of individual actors; co-governance, referring to co-operation, networking or public private partnerships and hierarchical governance, meaning 'traditional' top-down government. Apart from different forms, Kooiman also defines different levels of governance. It is different if a given political practice pursues solving concrete problems (first order-governance); (re-)organizing basic institutional settings (second order-governance) or building a normative framework for action (meta-governance).
Salet (2006, p. 2) suggests to define governance rather abstractly as a "framework for border crossing public action". This relates to crossing the border of different systems of regulation; of 'familiar' relationships of the public and private sector and of 'place bounded experiences of space.' Regarding the latter, the author means that the effects of social interaction that require governance usually do not correspond with the territorial jurisdiction of administrative organization.

One could imagine that the implementation of European policy is quite a complex matter in terms of governance. This is confirmed in the European Commission's White Paper on Governance (EC 2001) that pursues opening up the policy-making process to get more actors involved in EU policy: "The expansion of the Union's activities over the last fifteen years has brought it closer to regions, cities and localities, which are now responsible for implementing EU policies (...)" (p.12). At the same time, however, it is argued that "...the way in which the Union currently works does not allow for adequate interaction in a multi-level partnership; a partnership in which national governments involve their regions and cities fully in European policy-making." (ibid.)

Based on Bourdellon (2005), in this article governance is defined as 'a large partnership between the public and the private sector and the different layers of power' (Frank et al. 2006, p. 134). Linking the definition to the URBAN programme, the author even states that the central idea, its horizon and its conceptual framework, is governance. Governance is primarily approached as an institutional concept, connecting to Kooiman's modes and order of respectively 'co-governance' and 'second order governance'. Only when describing the contestation of authority between different governmental levels, also aspects of hierarchical governance will be emphasized. The impact of the European URBAN programme is described as changes of administrative acting and political planning structures, especially at the urban level.

The EU will be conceptualized as a multilevel polity under the keyword of 'multi-level governance.' This conceptualization offers analytical handles for examining the role and 'negotiations' of administrations at different levels within this polity, as related to the implementation of the European Community Initiative URBAN. What does 'multi level governance' exactly mean? 
Multi-level governance

In its conceptualisation of the European Union as a single, multi-level polity, the MLG model tries to capture changes in processes of decision-making and control over territories in all their complexity. Its point of departure is that there is an interconnectedness of ('supranational' and national) policy arenas and that subnational actors operate in both arenas at the same time; that authoritative decision making competencies have become dispersed across multiple territorial levels and that (political) control over activities in the territories has become shared (Heinelt 1996; Hooghe 1996; Marks 1996). Moreover, it is argued that processes of decentralization, in most European countries, have resulted in an increasing importance of the role of local governmental actors (Hooghe 1996). While one could wrongfully get the impression that multi-level governance merely deals with governmental levels, this is actually not the case: both public and non-public actors can be involved. Eising and KohlerKoch (2000) therefore speak of 'network governance' instead of multi-level governance.

Multi-level governance is often depicted as a negotiated order, emphasizing the ongoing dynamics. Marks (1996) refers to continuous negotiation among interconnected governments at supranational, national, regional and local territorial tiers. Boland (1999) tries to grasp the aspect of contestation by introducing the concept of 'contested multi-level governance.' Hooghe and Marks (2001) refer to the contested allocation of competencies between different levels. Peters and Pierre (2004, p. 75) emphasize that: "relationships among institutions at different tiers of government ... are believed to be fluid, negotiated and contextually defined," the latter part referring to the regulatory framework in which, according to the authors, multi-level governance is embedded. The multi-level governance model recognizes the fact that local actors such as cities have also become players within the European political arena and allows for an analysis of urban policy at the different levels of governance (Frank et al. 2006).

In view of Bourdellon's definition of URBAN as a large partnership, the accompanying mode of governance of the programme could be characterized as co-governance. As mentioned in the introduction, one could imagine that the implementation of this programme with its specific requirements on partnership and participation could give tensions in EU member states, especially if they have more hierarchical governance systems and centralist planning systems. Following this line of reasoning, in member states with a stronger focus on co-governance, this would be less the case.

The impact of URBAN on domestic governance structures and dynamics

Based on a model articulated by Green Cowles et al. (2001), Marshall (2005) argues that urban engagement with European Union policies results in a fourstage pattern of interaction and adjustment: European Union initiative (Structural Fund/Community Initiatives/Urban Pilot Projects); Adaptational pressures ('degree of fit' between European Union/domestic norms); Mediating institutions (local, regional, national institutional context) and finally, urban structural changes (institutional shifts/governance change).

An URBACT report published in 2006 (Frank et al. 2006) presents interesting results on the implementation of EU Community Initiative URBAN I and II programmes in European cities in Austria, France, Germany, Greece, Italy, the Netherlands and the United Kingdom. What has been their impact on domestic governance structures?

Almost all of the case and comparative studies in the report confirm an enormous effect of the programme, especially in terms of organizational structures and routines of proceeding. In many member states and cities a change of traditional governance modes is observed, triggered by URBAN. Especially in view of the restricted size and budget of the programme, this is a striking conclusion.

Traditional administrative structures were broken up and partnership-oriented URBAN committees were developed. These committees prepared, coordinated and controlled the organisational frameworks for the implementation of the programme measures. They usually also comprised other participants such as economic and social associations, external experts, private and entrepreneurial actors and community organizations (Frank et al. 2006).

At the political level these committees were crossdepartment (a co-operation of previously divided administration units) and cross-level (involving representatives of different levels of administration). At 
times, new forms of cooperation even resulted in a general re-structuring of municipal administrations. In Berlin, for example, the URBAN experience contributed to the amalgamation of the Senate Administration for Building and Housing and the Senate Administration for Urban Development and Environment into a 'super-Department' for Urban Development. Also in the examples of the French cities of Clichy-sous-Bois and Montfermeil URBAN has enhanced a close co-operation between different administrative sections (Frank et al. 2006; Güntner and Halpern 2006, p. 9; Bourdellon 2005). According to Frank et al. (2006), formally hierarchical relationships of, for instance, central-state and local administrations were even suspended for these meetings. In Manchester and Liverpool (UK), for example, strategic planning structures were institutionalized at the regional level without any co-ordination with central-state authorities.

At the same time, one should make the necessary differentiations in this general picture.

First, the governance impact of URBAN was stronger in some countries than in others. The most significant changes could be found in countries with a hierarchical and centralist tradition of planning, where the position of local authorities was relatively weak (Greece, Italy). Especially the inclusion of private non-state actors, as required by the European URBAN programme, was a significant innovation. Strong effects could also be found in countries that had already started changing their planning structures (Italy) or their urban-political orientations (UK). In these cases URBAN could function as a catalyst of already begun processes (Frank et al. 2006).

Moreover, the resulting form and elaboration of governance varied, even within countries. An interesting example concerns the composition of the URBAN-I Steering Committees in the Dutch cities of Amsterdam and The Hague. Both committees could be qualified as 'public public partnerships', in view of the fact that they had quite a large share of governmental representatives, but this was twice as much in The Hague. In the original composition of Amsterdam, the governmental share was $43 \%$ (3 out of 7), while in The Hague it was even $83 \%$ (10 out of 12). In Amsterdam, the three governmental members represented the municipality ( 1 out of 7 ) and the city district (2 out of 7); the city district was thus relatively strongly represented, as compared to the municipality. In The Hague, most of the governmental representatives ( 7 out of 10) represented the Municipality; the other 3 (out of 10) represented the Ministry of the Interior (at that time responsible for the implementation of the URBAN-I programmes in the Netherlands). In Amsterdam, the Ministry of the Interior was not represented in the Steering Committee, though (Table 1).

In both cities, the Chamber of Commerce participated, but in neither of them, residents' organizations were represented in the Steering Committee. ${ }^{3}$ The differences in this particular example might be explained by the public-administrative structure and the extent of administrative decentralization in the Netherlands: Dutch municipalities have constitutional standing and a relatively strong position in terms of implementation competences.

Second, there were critical comments concerning the profundity and sustainability of the governance changes caused by the URBAN programme.

The extent of decision power of the URBAN committees varied for different cities and the sometimes intricately organised webs of different committees acted at different implementation-levels of the URBAN programmes. Particularly the authority of decision making about the financial resources of the programmes often stayed exclusively with administratively led co-ordination committees. This was also the case in the Dutch cities of Amsterdam and The Hague: money flows from the European Structural Funds were sent directly from Brussels to the cities (without an intervening role for the Ministry of the Interior) and in the end the local authorities were responsible for the financial control and management of the URBAN-I programmes (the Ministry watching the financial implementation within the programmes).

In a number of case studies it was established that co-operation as required by URBAN was a considerable challenge for administrations. For that reason, in many cities external experts were included in the implementation of the URBAN programme, such as offices that had been contracted to implement other (mostly national) urban development programmes.

\footnotetext{
${ }^{3}$ In Amsterdam this issue caused a heated discussion that in the end resulted in a new organisation structure in which community groups were represented.
} 
Table 1 The URBAN-I Steering Committees in Amsterdam and The Hague

Source: Dukes 2006a, p. 289

\begin{tabular}{llll}
\hline Amsterdam & $N$ & The Hague & $N$ \\
\hline $\begin{array}{l}\text { Amsterdam Zuidoost City District } \\
\quad \text { (including the chair) }\end{array}$ & 2 & & \\
Amsterdam Municipality & 1 & The Hague Municipality & 7 \\
- & & Ministry of the Interior & 3 \\
Chamber of Commerce & 1 & Chamber of Commerce & 1 \\
Housing Association & 1 & - & 1 \\
- & & Regional Bureau Employment & \\
& & strategy (RBA) & \\
Managerial Consultation Education & 1 & - & \\
$\quad$ Zuidoost & & - & \\
Regional Police & 1 & & \\
Total & 7 & & \\
\hline
\end{tabular}

In practice, the actual inclusion of non-state actors was despite appearances often limited. Based on case studies of the Greek cities of Heraklion and Komotini, Chorianopoulos $(2005,2006)$ concluded that this was due to a considerable extent of inflexibility as an effect of the strongly centralist tradition of administration in Greece. In the case of Grenoble, France, it was often difficult for non-state actors to introduce their own ideas, as-often far more-experienced governmental officials already had ideas about what policy should look like. URBAN was then used as a supplement to already existing programmes. This was also the case in the Netherlands, where URBAN was connected to the Dutch national Big Cities Policy (Godayer 2002; Frank et al. 2006; Dukes 2006a).

In terms of sustainability it was questionable whether the established advisory council and planning structures, including non-state actors, would be lasting. Research results varied. In Northern Ireland the structures seemed to be lasting. In Belfast, for example, thanks to the central URBAN institution North Belfast Partnership, it was possible to establish and maintain a governance structure. Also in Italy, where the national government had started experimenting with integrated urban planning and programming, institutional changes and learning effects of URBAN were taken over (Frank et al. 2006). Other cases, however, point at changes of a more episodic nature, expiring with the running time of the programmes. In the Greek cases, for example, little evidence was found that changes enforced by EU requirements would have long-lasting effects (Frank et al. 2006). In the Dutch case of Amsterdam, when the URBAN-I programme was finished, local authorities (the Amsterdam Zuidoost City District Council) tried to establish an Advisory Board (Adviesraad) in which representatives of local organizations would participate, but their efforts failed (Dukes 2006a). At the same time, interestingly, what did happen was that the administrators of the Amsterdam Zuidoost City District joined a thematic network within URBACT, called 'UDIEX-UDIEX ALEP' (Urban Diversity and Inclusion Exchange) and thus became linked into a multi-level EU network.

The scope, profundity and sustainability of the governance changes thus varied. This raises the question whether there were particular (political, administrative or policy) circumstances that stimulated or hampered the impact of the changes.

A first interesting observation by Marshall (2005) was that in his British case studies (Birmingham and Glasgow) the impact of URBAN was limited, due to the fact that domestic urban programmes continued to operate according to path-dependent institutional norms and priorities dictated by the national authorities. This path-dependency seems to be confirmed in the Dutch case studies, where URBAN was connected to the Dutch 'Big Cities Policy' programme that had been introduced in 1994. However, as we will see in the next section, whether URBAN has impacted Big Cities Policy or whether it was the other way round has been contested in the discourse.

Earlier it was argued that both for Greece and Italy the organizational requirements of URBAN implied a significant innovation. Comparing the changes enforced by URBAN in these two countries, they did not have long-lasting effects in Greece, but they 
did in Italy. This might be explained by the fact that, as opposed to Greece, the national government in Italy had started innovation and experimentation with integrated urban planning and programming in the 1990 s. The URBAN programme met an openness and propensity to reform and functioned as an enforcer of processes that had already started (Frank et al. 2006).

Aside from the features of the existing planning system or openness for reform, also the political attitude towards European urban policy had a decisive influence on the impact of the programme. This was shown in a comparative study on Austria, Germany and Great Britain (Wolffhardt et al. 2005). Vienna, for example, was mainly engaged with Europe in order to prevent EU regulation that was perceived as a threat to its local policy tradition. In this particular case EU programmes did not shape the strategic orientation of the administration: the city operated the programmes exclusively through already existing bodies. Their impact on the domestic governance mode was thus relatively weak (Wolffhardt et al. 2005; Frank et al. 2006).

Another issue that opposed pressures by the URBAN programme was the gate keeping role of national governments, in pursuit of control over the policy process. URBAN cities were in close touch with European actors and often got a mediating position. This was not always appreciated and in some case studies a gate-keeping role of national governments was identified. ${ }^{4}$ This was, for example, the case in France, the UK and Greece.

Summarizing the foregoing, in many EU member states and cities the URBAN programme has had an impact, stimulating new forms of cooperation, networking, cross-departmental collaboration, partnership, participation, etc. At the same time, there has been considerable variation both between member states as well as between cities within them. Variations in impact of the programme might be explained by differences in domestic institutions and planning systems; the propensity to reform; the attitude towards EU regulations and the inclination of national authorities to keep control over the policy process. While the impact of URBAN might have been relatively substantial in view of its limited size and budget,

\footnotetext{
${ }^{4}$ For a more elaborate discussion on (extended) gatekeeping, see Bache (1996).
}

serious questions remain regarding the scope, the sustainability and the profundity of the URBAN induced governance changes.

Unfortunately, the overall picture of the governance impact of URBAN as presented in the URBACT report is somewhat crumbled, making it difficult to draw strong conclusions. This might be caused by the fact that a wide array of data sources has been combined.

Another interesting question is whether the European pressure on domestic governance structures and the resulting governance changes stimulated by URBAN have gone off without a struggle. This issue will be addressed by examining the role of European urban policy discourse. As the URBACT report does not address this particular topic, other sources will be used.

\section{The role of European urban policy discourse}

Focusing on the Netherlands and using a discourse analysis, the second research question addresses the role of European urban policy discourse as related to the governance impact of URBAN. Has the discourse been used for the 'negotiation' of governance issues? Has it been influential on discourses at different tiers of government? Before turning to these questions, it is important to clarify the concept of discourse and the methodology of discourse analysis.

Discourse and discourse analysis

Based on a definition by Phillips and Hardy (2002, p. 3), 'discourse' can be understood as an "interrelated set of texts and the practices of their production, dissemination and reception that brings an object into being." Discourse thus implies more than text only: there is also the crucial element of action, of bringing it into practice. Jørgensen and Phillips (2002) call it the 'functioning of discourse'. The meaning assigned to concepts in a discourse is not neutral, but politically laden and, for that reason, possibly contested. Besides, discourses might reflect the use of power in social relations between actors involved. This can be expressed, for example, in terms of particular ways of positioning of themselves and of other actors involved. Gate keeping by national governments serves as an example. This clearly 
reflects a political struggle between (in this case) actors at the national and the European governmental level. In terms of discourse, this could imply, for example, that national actors would depict themselves in relation to urban policy as 'legitimate actors' and European actors as 'intruders'.

Discourse analysis examines shared or divided meanings and the sometimes minimal changes in meanings and arguments. Next to examining place, actors, interests and institutions, the methodology provides instruments to describe how actors and organisations (re)frame their interests and arguments in order to solve a problem, or to (better) communicate, and 'sell' their interests. This adds a dynamic dimension to an analysis that is able to take into account interests and positions that transcend actorpositions (Van den Brink and Metze 2006, p. 14).

Analyzing European urban policy discourse

The analysis in this article is based on a methodology of Maarten Hajer (1993, 2003). He distinguishes three elements of discourse analysis: the study of the terms of policy discourse, the analysis of particular institutional practices, and the formation of particular discourse coalitions. The first element, the 'terms of discourse' refers to the ways in which institutional biases are structured in textual utterances. Hajer refines this element by introducing three different layers: story lines, myths and metaphors; policy vocabularies; and epistemic figures (certain rules of formation that underpin theories/policies). The second element of a discourse analysis, 'institutional practices', relates to the settings in which the discoursing takes place and conflicts are played out. The final element is the "coalition of actors that supports the discourse'; a group of actors that adheres to a particular social construct (Hajer 1993, p. 45).

The point of departure for the examination of European urban policy discourse has been the two main Communications in which the vision of the European Commission on urban policy has been laid down: Towards an Urban Agenda in the European Union (EC 1997) and Sustainable Urban Development in the European Union: A Framework for Action (EC 1998a). Additionally, several other documents have been used, in which specific guidelines, descriptions and assessments of the Urban Pilot Programme and the Community Initiative URBAN were described.
As general criteria for data selection, policy documents and spoken statements had to be produced by either the initiator of the urban programmes or by the civil service that carried them out. In case of EU sources, these were the European Commission and the Directorate General (DG) Regional Policy. Whereas the documents had to be qualified as official publications by the EU, the selected spoken statements had to be the official views of the Commission or cases in which the authors explicitly identified themselves with these official statements. Another criterion was that only texts and practices produced by 'insiders', that is directly involved actors, were considered.

Place and positioning in European urban policy discourse: EU sources

In case of EU sources fourteen documents were examined that either related directly to the two European area-based urban programmes (Urban Pilot Projects and the Community Initiative URBAN) or to the wider policy debates and the general vision of the European Commission on urban policy. ${ }^{5}$ What were the outcomes of the discourse analysis? Cities (or their parts) are, not surprisingly, the most important topic in the European urban policy discourse. The meanings assigned to them can be subdivided into four main categories: cities are depicted in terms of problems; as strategic potential that should be used and protected in order to safeguard the economic position of the European Union worldwide; as a balanced system (the 'urban system' within Europe) and as an entity of (formal) governmental responsibility, connecting directly to the issue who should be involved in dealing with particular issues in these cities.

Interestingly, European urban policy discourse seems to be rooted in and reflect a political struggle between various governmental levels in the European polity, prompted by processes of European integration and Europeanization. This is, for example, expressed in ways of (self) positioning: one finds recurring patterns regarding the extent of appearance of actors in the discourse; the undertone of the meaning assigned to them and their positioning in relation to each other. European urban policy makers

5 For an elaborate data selection and analysis, see Dukes (2006a, b). 
position themselves as political actors in the discourse. Their role in urban policy seems beyond dispute: "Some urban challenges can only be tackled effectively if the European Union plays its part" (the then Secretary General of the European Commission Trojan 1998, p. 8). In view of the lengthy discussions during the past years about the subsidiarity principle, the following defensive statement does not come as a surprise: "For a number of reasons, European Union involvement is justified and has a clear added value" (the then Secretary General of the European Commission Trojan 1998, p. 7). Strikingly, the possible positions of the EU that are brought up do not address any aspects related to the formal authority of EU bodies in urban issues. They are merely phrased in terms of roles that neither discord with the subsidiarity principle nor with the formal authority of other (sub-) national actors. Interesting in this sense is the title of a 1998 factsheet: 'URBAN: restoring hope in deprived neighbourhoods' (EC 1998b). It implies the construction of its initiator, the European Commission, as a helper of citizens in need.

Member States, on the other hand, are often positioned in a critical way. While their formal position is not contested in the discourse, at times, their attitude is. The elaborate discussion on the subsidiarity principle, the contestation over the issue of partnership within European Regional policy and the Structural Fund operations (who is involved and who should be involved) but also (within the particular case of urban policy) criticism on the member states because of their attitude towards local partnership, serve as examples.

Cities, finally, are depicted as being in favour of partnership; as an important partner of the European Commission and as governmental authorities with whom the Commission has a special and self-evident alliance. One final example derived from Secretary General Trojan's speech refers to the EU as 'a natural ally of the European city' (1998a, p. 8).

Place and positioning in European urban policy discourse: Dutch national sources

In order to get an idea of the impact of European urban policy discourse on different tiers of government and its use for the negotiation of governance issues by actors involved, an examination was made of Dutch sources as well.
For the discourse analysis of Dutch national sources, various (policy) documents were used that had been produced by the Ministry of the Interior, as well as speeches that had been given by former Ministers of urban policy. All the selected documents, that roughly covered the 1994-2004 time period, dealt with European urban programmes and often also, coherently, with Dutch Big Cities Policy. The speeches, all given for an audience of a wide variety of actors, were chosen based on the extent in which they dealt with 'urban issues' at the national and at the European level.

Comparing Dutch national sources related to European urban policy with European sources on this topic, there is a certain homogeneity in the discourse. This is expressed, for example, both in the policy vocabulary, which partly overlaps, as well as in the policy approach (area-based, integrated policy). Not all the key words that are used are the same, though. Differences might be explained by the various different (institutional, discursive, etc.) contexts in which they are produced and embedded.

At the same time, just this homogeneity in the discourse offers opportunities for contestation of particular constructions within it. At times, ways of (self)positioning and meanings assigned express contestation of the position of the European Commission as related to urban policy. Claims are either very abstract or concern more concrete issues like taking initiatives or allocating roles. According to the then Minister of Internal Affairs Dijkstal (1997), for example, "in the autumn of 1996 the Netherlands ... decided to place the question of urban development on the European agenda during the Dutch presidency of the EU." National policy makers position themselves indirectly, through positive qualifications of their 'Big Cities Policy'. This Dutch national policy is explicitly put forward as the national policy framework in which European urban programmes are embedded, even though the national government is actually not able to get round the requirements related to European Structural Fund programmes such as URBAN. Through constructions of national urban policy at the European level ('European Big Cities Policy') national policy makers even seem to exceed their own level of authority. And while the European Commission is often praised for its initiatives, at the same time, 'Brussels' is criticized. In a wider context, this struggle might reflect the fear for 
European interference in internal affairs, judging, for example, the construction of European regulations in terms of danger.

Place and positioning in European urban policy discourse: Dutch local sources

Interestingly, the picture is totally different if one examines the discourse in Dutch local sources. The URBAN-I programmes that were implemented in Amsterdam and The Hague in the second half of the $1990 \mathrm{~s}$, for example, were embedded in particular local (policy) frameworks: urban renewal (The Hague) and the Bijlmermeer renewal operation (Amsterdam) respectively. These local frameworks were clearly taken as the point of departure and the two operational URBAN-I programmes were drawn up in an official and highly pragmatic way. If one examines the discourse in these sources, no discursive approaches at all were made towards the European Commission in whatever positive or negative way. URBAN was a relatively small programme that was mainly constructed in terms of money: as co-financing of the Dutch Big Cities Policy. More generally speaking, in the mid $1990 \mathrm{~s}$, there was still a lack of interest in political matters vis-à-vis Europe at the municipal level of Amsterdam and The Hague. Local politics did not yet focus on Europe and a European urban political arena was still absent. European matters were still mostly dealt with on an ad hoc basis. European urban policy discourse did not seem to be absorbed in local sources concerning urban policy. This might also explain why the city governments did not seize the opportunities that the European Commission offered in positioning the cities as 'partners of the European Commission'. The possible 'strategic value' for positioning themselves and/or the European Commission in the European urban policy arena was either overlooked or played down. A uniform EU oriented discourse, as input towards the EU, has not been developed either.

In conclusion, comparing European Urban Policy Discourse in European and Dutch sources, it partly overlaps and partly differs. While one could argue that the overlap in key words used in European and national sources can be ascribed to the impact of European urban policy discourse, one could also argue that it points at the existence of an urban policy network in which actors address similar topics and concerns, using similar words and-at times-similar constructions of cities. The latter explanation seems more plausible. For years the European Commission, the member states, other governmental levels and others have been in touch with each other about European urban policy; formally and informally, through networks, at conferences, and so forth. At the same time within this discourse actors contest each others' authority as related to urban issues. In Dutch sources related to European urban policy, however, this struggle is merely visible at the national level and not at the local level. In view of the discourse in Dutch local sources of Amsterdam and The Hague, in the mid $1990 \mathrm{~s}$ the city administrators' interest for Europe was clearly still in its infancy and their participation in the 'urban networks' still relatively modest.

\section{URBAN as an instrument of Europeanization}

In section two it was concluded that URBAN has induced governance changes but that questions remain regarding the scope, sustainability, and profundity of these changes. Section three points at an overlapping discourse with elements of a discursive political struggle between actors at the European and the Dutch national level. Striking is the fact that the discourse on European urban policy is absent at the local level. URBAN induced governance changes and the presence of European urban policy discourse directly connect to an interesting issue: their possible role in the process of Europeanization.

Whereas, in our view, the contribution of the URBAN programme to the process of Europeanization, should be assessed in modest terms, according to Frank et al. (2006, p. 147), it should be considered as an "essential element of Europeanization in the field of urban policy". This element of Europeanization is not an easily definable phenomenon, though. The authors themselves argue that it is impossible to decouple the Europeanization of domestic urban policies from other fields of European integration and to look at it separately. Marshall (2005) points at the diverse points of contact between European and urban territorial systems, through partnerships, transnational organizations and networks, town twinning, cultural exchanges, etc. that render it difficult to establish the extent of Europeanization. At the same 
time, the author tries to examine this phenomenon at the local level, presenting 'Urban Europeanization' as a new analytical paradigm for the examination of policies, practices, preferences and participants.

Differentiating between regional adaptation (one of the chief themes of the evolving Europeanization research agenda) and Europeanization at the urban level is crucial, Marshall argues, as urban institutions and actor behaviour are shaped by highly specific opportunities and constraints. The types of adjustment within cities and metropolitan sub-regions are far more subtle. Moreover, any approach or investigation should analyze both the effects of EU policies and programmes on cities and the role of cities within the European process of decision-making.

Before exploring the validity of the statements about the contribution of URBAN and European urban policy discourse to Europeanization in more detail, it is important to briefly address the meaning of 'Europeanization' first.

Aspects and directions of Europeanization

While European integration is primarily concerned with the question to what extent member states devolve authority to supranational bodies, Europeanization focuses on the processes within these member states after authority has been devolved (de Rooij 2003). Bache and Marshall (2004, p. 5) define Europeanization as: "the redirection or reshaping of politics in the domestic arena in ways that reflect the policies, practices or preferences of EU level actors/ institutions." Marshall (2005) argues that in order to assess the impact of Europeanization at the urban level, one could examine the policies, practices and preferences affected by interaction with the EU. At the same time, however, in order to account for the unique political networks that dominate territorial politics at the urban level, one should also study the participants involved. This definition and the four units of analysis offer a good point of departure for examining Europeanization at the urban level, focusing in particular on structural governance changes and European urban policy discourse.

Generally speaking, studies reveal a considerable variation in the process of Europeanization across the member states (Harmsen 1999; Green Cowles, Caporaso and Risse 2001; Bache and Marshall 2004). This uneven process is presently explained with reference to a neo-institutionalist framework, drawing in particular on the work of March and Olsen (1984, 1989). Adaptation reflects the pre-existing domestic institutional structures and values. National administrations will, literally, seek to domesticate the integration process (Harmsen 1999; Olsen 2002). Gate keeping in order to keep control over the policy process serves as an example. In Marshall's opinion, "Europeanization, far from reducing local fragmentation, actually serves to accentuate it, prompting the development of more urban partnerships, widening the number of participants involved in decisionmaking and encouraging greater multi-level territorial interaction" (Marshall 2005, p. 673).

Based on Marshall, Frank et al. (2006) make a distinction between 'download Europeanization' and 'upload Europeanization'. 'Download Europeanization' describes changes in policies, practices, preferences or participants within local systems of governance, arising from the negotiation and implementation of (in this case European urban) programmes. 'Upload Europeanization' implies the transfer of innovative and best urban practices to the supranational arena resulting in the incorporation of local initiatives in pan-European policies or programmes. In the following, this distinction will be taken as the point of departure.

Marshall (2005, p. 673) distinguishes four varieties of Europeanization in cities that participate in EU Structural Fund programmes, the URBAN Community Initiative or Urban Pilot Projects: Europeanization of local government; of non-state actors involved in processes of urban renewal and governance and of local regeneration partnerships and networks (all 'download') and Europeanization that engenders dissemination of local practices to the supra-national level, and thus to other cities via trans-national networks ('upload and crossload'). One could, however, also think of Europeanization of institutional practices, such as behaviour or discourse (de Rooij 2003; Dukes 2006a).

\section{Download Europeanization through URBAN}

The URBACT report presents examples of 'download Europeanization' in many European countries: a reorganization of local urban governance, in which URBAN acts as a catalyst for change in terms of more EU oriented policy practices; a stronger orientation 
towards partnerships, strategic planning, integrated and area-based policy approaches and increasing co-operation with citizens' groups and community organizations. Graz (Austria) is presented as the perfect example of a successful and sustainable process of Europeanization in the field of urban governance triggered by the URBAN programme (Wolffhardt et al. 2005; Frank et al. 2006).

Frank et al. (2006) even establish that in eight EU member states ${ }^{6}$ area-based programmes have been set up with characteristics of an integrated, innovative, and bottom-up policy approach. The authors see this as an indicator of significant influence of the European URBAN programme and thus as evidence for Europeanization in the field of urban policy triggered by URBAN. While we do not question some impact of URBAN, this particular example needs qualification. Earlier it was mentioned that an urban policy network came into being in the $1990 \mathrm{~s}$, in which the European Commission, member state officials of different governmental levels and others have been in touch with each other about several aspects of European urban policy through conferences etc. It seems plausible that ideas have been exchanged in this network resulting in growing similarities in European and national urban policies. In case of the Netherlands, for example, in 1994 a national area-based urban policy framework 'Big Cities Policy' was introduced. This Dutch programme was quite similar to the European URBAN programme: it was also area-based; followed an integrated approach; encouraged local participation and required co-operation between actors at different governmental levels. It cannot be considered as an example of a national policy molded after European prescriptions. Dutch national authorities even suggested that:

"The Netherlands envisages contributing its integrated policy to the European strategy ...."

(Ministerie van Binnenlandse Zaken en Koninkrijksrelaties 2001, page not indicated).

To what extent could one speak of 'download Europeanization' in the case studies of the Dutch cities of Amsterdam and The Hague? The composition and way of working of the URBAN Committees was new, but not sustainable; the organization structure merely lasted for the duration of the programme.

\footnotetext{
${ }^{6}$ Austria, Denmark, France, Germany, Italy, Sweden, The Netherlands and the UK.
}

While Amsterdam and The Hague generated some EU focused activities in the early $1990 \mathrm{~s}$, prompted by the approaching European Summit of Maastricht, a more permanent EU engagement of the two municipalities developed only gradually. When the URBAN-I programmes were implemented, the local authorities did not seem to be ready for an active political attitude towards Europe yet. The programmes were mainly dealt with by civil servants and URBAN was embedded in existing local policy frameworks. The latter were taken as the point of departure, also discursively. The extent of download Europeanization thus seemed to be quite low in terms of discourse. But the local authorities were gradually raising the European profile of their cities and in the early $2000 \mathrm{~s}$, when the URBAN-I programmes had just been finished, Europe became a topic of importance on the local political agenda, also as regards urban policy. In this period there were also other forms of EU engagement going on. Already in the early $1990 \mathrm{~s}$ (1991 and 1993, respectively), for example, Amsterdam and The Hague had joined the Eurocities network. Over time, they also became a member of various other city networks. Moreover, possibly as part of its pursuit of becoming the 'Legal Capital of the World', especially The Hague showed a remarkable and increasing administrative involvement in bodies such as the Committee of the Regions, the Council of European Municipalities and Regions (CEMR) and the Eurocities network. No doubt, the growth of such links has also influenced policies, practices, preferences and participants within municipal governance systems. It is possible that URBAN programmes played some part in the ongoing 'download Europeanization' in the urban policy area in these cities, but it can hardly have been a major part.

\section{Upload Europeanization through URBAN}

'Upload Europeanization' in the sphere of urban policy implies the transfer of innovative and best urban practices to the supranational arena resulting in the incorporation of local initiatives in pan-European policies or programmes. The case studies in the URBACT report only give a few examples of a successful transfer of innovative experiences, but they might not be exhaustive, as the authors emphasize that this topic is a rather neglected field of research in the report. 
One could argue, though, that URBAN has furthered the mutual, transnational contacts between European cities and has thus stimulated the exchange of knowledge and practices (a matter of 'trans-load' or 'cross-load' Europeanization). The international URBACT network itself serves as a good example: this network (officially it is called a 'programme') favours networking between cities in which European Urban Pilot Projects, URBAN-I or URBAN-II programmes have been implemented. Its objectives are threefold: developing trans-national exchanges of experience between cities; capitalizing lessons learned from the analysis of those experiences and disseminating this knowledge to all actors in European cities.

It is questionable whether the URBACT programme also adds to upload Europeanization, for its primary emphasis is exchanging knowledge and practices. Its main focus is creating and managing thematic networks and working groups. These are built around particular themes and collect and analyze good practices in economic and social regeneration. The themes cover topics such as social exclusion; inclusion of populations of foreign origin; integration of young people; economic activity and employment; citizen participation; and so forth. However, exchanges of knowledge and practices do not necessarily imply their transfer to the supranational arena. In other words, there is not necessarily collective 'upload Europeanization' from within URBACT. This is very different in the case of Eurocities. That network has an explicit political goal and actively engages in lobby activities vis-à-vis the European Commission. However, the Eurocities network has certainly not been formed under the influence of URBAN, for it was established in 1986 already.

At the same time, however, many cities actively aim individually at increasing their influence at the EU level through city networks that often function as a place of political organization of Europe. Of course, European programmes in these cities might partly have stimulated their membership, but this is not necessarily the case. Wolffhardt et al. (2005, p. 39) refer to cities involved in this type of European engagement as 'profiling, self-styled Euro-players'. In the URBACT report, Vienna and Manchester are referred to as examples. But also the Dutch city of The Hague matches the profile. While The Hague still positioned itself in 1993 as an entity undergoing
European influence (download, passive), primarily occupied with acquiring European subsidies, at the end of the $1990 \mathrm{~s}$, the city positioned itself as an entity that influenced European policy (upload, active). In terms of Europeanization, once more, it should be emphasized that it is difficult to fully attribute the increasing pro-active attitude of The Hague towards the European Union to the URBAN (and following) European programmes that have been implemented in the city.

Summarizing the foregoing, the Community Initiative URBAN can be considered one more stage in the long process of European integration and Europeanization, in this case within the urban policy domain. At the micro-scale it demonstrates the ongoing struggle for power between actors at the European and the national governmental level, as expressed in European urban policy discourse. In the mid $1990 \mathrm{~s}$, (Dutch) local authorities did not (yet) participate in this discourse. It did not contribute to Europeanization at the urban level, neither upward, nor downward. This has changed in the following years, when cities increasingly became actively involved in transnational networks, often stimulated by URBAN. These networks have resulted in new forms of 'trans-load' Europeanization and in an increasing EU orientation that may well result in further download and upload Europeanization.

\section{Conclusion}

The European Community Initiative URBAN, explored in this article for seven countries in general and for two individual cities in the Netherlands in particular, is a micro example of the ongoing struggle between European and national policy actors who contest each others' authority. The programme, aimed at solving social-economic problems in deprived neighbourhoods in European cities, has acted as a catalyst for new forms of cooperation, through its requirements of local partnership and participation. This has particularly been the case in countries with a centralized tradition of urban planning where such innovations were called for. Their introduction was apparently more successful if national authorities had already become convinced that such changes were necessary. Whether URBAN has directly contributed to Europeanization at the 
local level seems questionable, at least in the Netherlands, where this has been studied in some detail. But participation in the programme helped Dutch city administrations to enter the European stage either individually or through trans-national networks. Whereas the typical European urban policy discourse, the jargon that came into being in connexion with the development of European urban policy, could not be found at the level of Dutch city administrations in the mid $1990 \mathrm{~s}$, more recently, through these networks, the discourse has become dispersed and is now increasingly used in local political arenas.

Open Access This article is distributed under the terms of the Creative Commons Attribution Noncommercial License which permits any noncommercial use, distribution, and reproduction in any medium, provided the original author(s) and source are credited.

\section{References}

Anderson, J. J. (1995). Structural funds and the social dimension of EU Policy: Springboard or stumbling block? In S. Leibfried \& P. Pierson (Eds.), European social policy; between fragmentation and integration. Washington, DC: The Brookings Institution.

Bache, I. (1996). EU regional policy: Has the UK Government succeeded in playing the gatekeeper role over the domestic impact of the European regional development funds? Unpublished $\mathrm{PhD}$ thesis, University of Sheffield.

Bache, I., \& Marshall, A. J. (2004). Europeanization and domestic change: A governance approach to institutional adaptation in Britain. Queen's Papers on Europeanization No. 5/2004. http://ideas.repec.org/p/erp/queens/p0046.html.

Boland, Ph. (1999). Contested multi-level governance: Merseyside and the European Structural Funds. European Planning Studies, 7(5), 647-664.

Bourdellon, B. (2005). L'européanisation des systèmes d'action locale: la traduction du programme d'initiative communautaire Urban sur le site de Clichy sous Bois Montfermeil. Mémoire de fin d'études 2004-2005.

Chorianopoulos, I. (2005). Tackling social exclusion in urban areas: A break with the past. Paper presented at the 3rd ECPR Conference, Budapest, September 8-10, 2005.

Chorianopoulos, I. (2006). The case of Heraklion URBAN in Greece: Regulatory responses to EU challenges. Paper presented at the European urban policy and URBAN researchers workshop, Humboldt University Berlin, April 7-8, 2006

Christiansen, T., Jorgensen, K. E., \& Wiener, A. (1999). The social construction of Europe. Journal of European Public Policy, 6(4), 528-544.

Cowles, M. G., Caporaso, J., \& Risse, T. (Eds.). (2001). Transforming Europe: Europeanization and domestic changes. Ithaca: Cornell University Press. de Rooij, R. A. A. (2003). Nederlandse gemeenten en provincies in de Europese Unie: Gevolgen van het nationale EU-lidmaatschap voor subnationale overheden. Deventer: Kluwer.

Dijkstal, H. F. (1997). Speech by Deputy Prime Minister Hans Dijkstal at the 10th annual general meeting of Eurocities, regional centres, on 23 October 1997 in Rotterdam.

Dukes, T. (2006a). Place, positioning and European urban policy discourse: Examples of politics of scale in 'Brussels' and the Netherlands, $\mathrm{PhD}$ thesis, University of Amsterdam, Amsterdam.

Dukes, T. (2006b). Who rules the area? Place and positioning in European urban policy discourse. In M. van den Brink $\&$ T. Metze (Eds.), Words matter in policy and planning: Discourse theory and method in the social sciences (pp. 103-115). Utrecht: Netherlands Geographical Studies.

Eising, R., \& Kohler-Koch, B. (2000). Introduction: Network governance in the European Union. In B. Kohler-Koch \& R. Eising (Eds.), The transformation of governance in the European union (pp. 3-13). London: Routledge.

European Commission. (1997). Towards an urban agenda in the European Union. COM (97) 197 final.

European Commission. (1998a). Sustainable urban development in the European Union: A framework for action. COM (98) 605 final.

European Commission. (1998b). URBAN: Restoring hope in deprived neighbourhoods. Fact Sheet 15-11-1998.

European Commission. (2001). European governance: A white paper. COM (2001) 428 final.

Frank, S., Holm, A., Kreinsen, H. \& Birkholz, T. (2006). The European URBAN experience-seen from the academic perspective. Study Report. Study project funded by the URBACT programme. Berlin: Humboldt Study Team.

Godayer, L. (2002). Le Programme d'initiative communautaire Urban. Quand la politique de la ville devient européenne. Etude du Pic Urban de l'agglomération Grenobloise, Séminaire Habitat et Société 2001-2002. URL: http:// www.urban-france.org/2005.2/site/public/v_fr/contenu_ v2002/document_download.php?ts $=1196626915 \& \mathrm{rub}=$ documentation $\&$ is $=268432 \& \mathrm{cs}=1196626915 \&$ ip $=618 \&$ idoc $=$ 1118.

Güntner, S., \& Halpern, Ch. (2006). Urban regeneration in Berlin and the EU (1990-2004): A deepening relation? In L. Doria, V. Fedeli \& C. Tedesco (Eds.), Rethinking EU spatial policy as a hologram. London: Ashgate.

Hajer, M. (1993). Discourse coalitions and the institutionalisation of practice: The case of acid rain in Britain. In F. Fisher \& J. Forester (Eds.), The argumentative turn in policy analysis and planning (pp. 43-76). Durham: Duke University Press.

Hajer, M. (2003). A frame in the fields: Policymaking and the reinvention of politics. In M. A. Hajer \& H. Wagenaar (Eds.), Deliberative policy governance: Understanding governance in the network society ( $\mathrm{pp} .88-110)$. Cambridge: Cambridge University Press.

Harmsen, R. (1999). The Europeanization of national administrations: A comparative study of France and the Netherlands. Governance: An International Journal of Policy and Administration, 12(1), 81-113.

Heinelt, H. (1996). Multi-level governance in the European Union and the structural funds. In H. Heinelt \& R. Smith 
(Eds.), Policy networks and European structural funds (pp. 9-25). Brookfield, USA: Avebury.

Hooghe, L. (1996). Introduction: Reconciling EU-wide policy and national diversity. In L. Hooghe (Ed.), Cohesion policy and European integration: Building multi-level governance (pp. 1-24). New York: Oxford University Press.

Hooghe, L., \& Marks, G. (2001). Multi-level governance and European integration. Lanham, USA: Rowman and Littlefield.

Jørgensen, M., \& Phillips, L. (2002). Discourse analysis as theory and method. London: Sage.

Kooiman, J. (2003). Governing as governance. London: Sage Publications.

March, J. G., \& Olsen, J. P. (1984). The new institutionalism: Organizational factors in political life. American Political Science Review, 78, 734-749.

March, J. G., \& Olsen, J. P. (1989). Rediscovering institutions: The organizational basis of politics. New York: The Free Press.

Marks, G. (1996). Exploring and explaining variation in EU cohesion policy. In L. Hooghe (Ed.), Cohesion policy and European integration: Building multi-level governance (pp. 388-452). New York: Oxford University Press.

Marshall, A. (2005). Europeanization at the urban level: Local actors, institutions and the dynamics of multi-level interaction. Journal of European Public Policy, 12(4), 668-686.

Ministerie van Binnenlandse Zaken en Koninkrijksrelaties. (2001). Communautair Initiatief Urban 1995-1999 voor steden in Nederland: Europees Grote Steden Beleid (uitgave 2).

Olsen, J. P. (2002). The many faces of Europeanization. ARENA working papers, WP 01/2, Oslo: ARENA. http://eiop.or.at/erpa/arena.htm.
Peters, B. G., \& Pierre, J. (2004). Multi-level governance: A Faustian bargain? In I. Bache \& M. Flinders (Eds.), Multilevel governance (pp. 75-89). Oxford: Oxford University Press.

Phillips, N., \& Hardy, C. (2002). Discourse analysis: Investigating processes of social construction. Thousand Oaks: Sage.

Pierre, J. (2000). Introduction: Understanding governance. In J. Pierre (Ed.), Debating governance: Authority, steering and democracy (pp. 1-10). Oxford: Oxford University Press.

Salet, W. (2006). The Myth of immediacy: Reflecting the institutional dimension in fovernance Discourse. EUREX Lecture, April 5, 2006. http://shiva.uniurb.it/EUREX/.

Trojan, C. (1998). Agenda 2000 and the role of cities. Speech presented at the Eurocities Seminar, European Parliament Building, Brussels May 26th.

van den Brink, M., \& Metze, T. (2006). Words matter in policy and planning. In M. van den Brink \& T. Metze (Eds.), Words matter in policy and planning: Discourse theory and method in the social sciences (pp. 13-20). Utrecht: Netherlands Geographical Studies.

Wolffhardt, A., Bartik, H., Meegan, R., Dangschat, J.S., Hamedinger, A. (2005). The European engagement of cities. Experiences, motivations and effects on local governance in Liverpool, Manchester, Vienna, Graz, Dortmund and Hamburg. In E. Antalovsky, J. S. Dangschat, \& M. Parkinson (Eds.), European metropolitan governance. Cities in Europe-Europe in cities (pp. 65112). Wien: Europaforum Wien. 